\title{
A Review of Methods for Reduction of Polycyclic Aromatic Hydrocarbons from Waste Water and Flue Gases
}

\author{
Semjonova I., Teirumnieks E. \\ Rezeknes Augstskola (Rezekne Higher Education Institution), Faculty of Engineering. Address: \\ Atbrivosanas aleja 76, Rezekne, LV-4601, Latvia. Tel./Fax: +371 64625167, e-mail: \\ indra_semjonova@inbox.lv,edmunds@ru.lv
}

\begin{abstract}
This review describes methods which can be used for the reduction of the polycyclic aromatic hydrocarbon (PAH) emissions from wastewater and flue gases including principles of operation of the methods and studies of their effectiveness. There are discussed both methods, which nowadays are already used industrially, and their improvement opportunities as well as recent technological trends in this field. The methods have been classified into two main categories: flue gas treatment and wastewater treatment.
\end{abstract}

Keywords - polycyclic aromatic hydrocarbons, wastewater, flue gas, reduction.

\section{INTRODUCTION}

Polycyclic aromatic hydrocarbon compounds are class of complex organic compounds that contain two or more fused aromatic rings. These compounds are widely distributed in the environment and is one of the first atmospheric pollutants have been identified as potentially carcinogenic. Today they are recognized as highly carcinogenic and mutagenic compounds, and therefore part of them the U.S. Environment Protection Agency and the European Community regulated as priority pollutants [7].

Polycyclic aromatic hydrocarbons mainly are products of incomplete combustion and organic matter pyrolysis. They may originate from both natural and anthropogenic sources. A small portion of PAHs are released into the environment from natural sources such as forest and grassland fires or volcanic eruptions, but mainly they originate from human-made sources. Anthropogenic sources can be divided into two groups: pyrogenic and petrogenic. Pyrogenic PAHs are formed during combustion of fossil fuel and biomass (vehicle exhaust, waste incinerators, power plants), but petrogenic PAHs during combustion of crude oil and its products $[8,6,52]$. Nowadays there are different methods for treating flue gases and effluents to reduce emissions into the environment.

\section{MATERIALS AND METHODS}

This article is a review of the scientific literature, therefore it was gathered and analyzed available information on the chosen topic. Based on it there was carried out an assessment of the performance of the currently used and potential methods and their intercomparison.

\section{RESULTS AND DISCUSSION}

Flue gas treatment

Polycyclic aromatic hydrocarbons due to their high volatility can be released in the environment not only in the particulate matter (PM) but also in the gas phase [7]. The PAH gas/solid partitioning is related to the liquid ambient temperature, vapour pressure, chemical composition, size and the surface area of the PM [8]. These characteristics combined with the PAHs volatile character determine the way in which they are emitted from a combustion process [6].

Partial elimination of PAHs can be achieved by capturing the particulate matter, which is carried out by conventional gas-cleaning systems such as cyclones, bag filters, scrubbers and electrostatic precipitators.

\section{Cyclone separators}

Cyclone separators are well known in the field of particle separation and collection from gas streams. Basically, a cyclone separator receives a gas stream and passes it through cylindrical conical housing thereby forming a vortex such that particles therein are separated from the gas stream and pass out a discharge outlet while the cleaned gas passes through a cleaned gas outlet. It is a centrifugal force created by the action of the vortex thus leaving the cleaned gas at the vortex center, where the cleaned gas continually flows outwardly through the clean gas outlet [52].

\section{Bag filters}

Bag filtration is one of the most reliable, efficient, and economic methods for removing particulate matter from gases. Bag filter provides a second filter stage for removing dust from air discharged from a cyclone or other primary separator. In the bag filter dust is filtered from the air, which is discharged through the filter walls. The filtered dust is conveyed along the bottom of the bag 
filter by an air conveyor and is recirculated back to the primary separator for removal thereat. Fabric or cloth filters in the form of tubular bags are generally used for gas filtration [43].

\section{Wet scrubbers}

In wet scrubber system an air stream containing the dust is wetted with water and impinged onto an impingement board which removes the major part of the dust as a mixture of dust and water. Wet scrubbers are used due to their high removal efficiency for coarse particles (1-2 $\mu \mathrm{m}$ in range), small onsite plot space, no problems at high temperatures $[76,5]$.

Electrostatic precipitators

Electrostatic precipitator having strong electrical field is generally used for the collection of particulate matter or dust. There are two general types of electrostatic precipitators, single-stage in which ionization and collection are combined, and two-stage in which the ionization is achieved in one zone and collection in other zone [44].

These types of air pollution control devices did not show high removal efficiencies for pollutants such as PAHs (Table 1). In two batch-type medical waste incinerators shared the same air-pollution control devices which were installed in series, including one electrostatic precipitator and one wet scrubber, were analyze the concentrations of $21 \mathrm{PAH}$ species contained in the stack flue gas. The results showed that removal efficiencies of total PAHs by the air pollution control devices were only $15.2 \%$ and $15.4 \%$. While the removal efficiencies of total PAHs in Taiwan joss paper furnace, which was equipped with a cyclone and a wet scrubber, was $42.5 \%$ and $11.7 \%$, respectively. There were studied also emissions from batch hot mix asphalt (HMA) plants and PAH removal efficiencies associated with their installed air pollution control devices (cyclone and bag filter). The overall removal efficiency of the installed air pollution control devices on total PAHs and total $\mathrm{Ba}_{\mathrm{Peq}}$ were $22.1 \%$ and $93.7 \%$, respectively. This implies that the installed air pollution control devices have a very limited effect on the removal of total PAHs [77, 34, 78].

$$
\text { TABLE } 1
$$

PARTICLE-BOUND PAH REMOVAL EFFICIENCY OVER VARIOUS METHODS [34, 78, 77]

\begin{tabular}{|c|c|c|}
\hline Method & Substance & $\begin{array}{c}\text { Removal } \\
\text { efficiency, } \\
\text { \% }\end{array}$ \\
\hline $\begin{array}{c}\text { Cyclone } \\
\text { separator }\end{array}$ & Total PAHs & 42.5 \\
\hline $\begin{array}{c}\text { Cyclone } \\
\text { separator }+ \\
\text { bag filter }\end{array}$ & Total PAHs & 22.1 \\
\cline { 2 - 3 } & Benzo[a]pyrene & 93.7 \\
\hline Wet scrubber & Total PAHs & 15.4 \\
\cline { 2 - 3 } & Total PAHs & 11.7 \\
\hline $\begin{array}{c}\text { Electrostatic } \\
\text { precipitator }\end{array}$ & Total PAHs & 15.2 \\
\hline
\end{tabular}

The gas-phase PAH emissions must be tackled by developing specific technologies, like those described below.

\section{Catalytic oxidation}

The metal $(\mathrm{Mn}, \mathrm{Co}, \mathrm{Cu}, \mathrm{Fe}$, and $\mathrm{Ni}$ ) oxides or noble metals (Pt, Pd, $\mathrm{Rh}$, and $\mathrm{Au}$ ) supported catalysts have already been studied to destroy organic pollutants. Noble metals possess higher catalytic activity and selectivity for the oxidation of organic compounds at low temperature, but, because of their much higher cost, base metals have been more widely investigated for oxidation of organic compounds [78, 66, 59, 71, 19]. Most researchers used naphthalene as a probe molecule to develop efficient catalysts for PAHs destruction. These studies are mostly focused on naphthalene total combustion on different noble metal and some supported metal oxide catalysts, supported on $\gamma-\mathrm{Al}_{2} \mathrm{O}_{3}$. Among them, $\mathrm{Pt} / \mathrm{Al}_{2} \mathrm{O}_{3}$ is recognized as one of the most active catalysts. The effects of support and other metal additives on Pt-based catalysts have also been considered for the improvement of naphthalene oxidation, such as $\mathrm{SiO}_{2}, \mathrm{SnO}_{2}, \mathrm{TiO}_{2}, \mathrm{CeO}_{2}$ and $\mathrm{V}_{2} \mathrm{O}_{5}[80,42,27,81,26]$. There is also investigated an application of ozone in conjunction with $\mathrm{Pt} / \mathrm{Al}_{2} \mathrm{O}_{3}$ catalysts, called ozonecatalytic oxidation (OZCO) process, to destruct gaseous naphthalene to enhance the performance of catalytic oxidation [53].

\section{Active carbons}

Active carbons are considered a promising technological solution for the PAH emission control due to their low price, high surface/weight ratio, easy handling and, usually, appropriate for regeneration in cycles $[53,1$, 9]. The gas is generally passed through a bed of activated carbon where the molecules of the contaminants are transferred to the solid phase (adsorption process). It was shown that the main factors controlling the adsorption process are microporosity, mesoporosity and pore size distribution $[1,11,13,14,12]$.

As it can be seen in Table 2, the removal efficiency of the catalytic process depends also on metal loading. Besides, improved PAH removal can be achieved using $\mathrm{HNO}_{3}$ and $\mathrm{NaOH}$ as pretreatment solutions.

\section{Electron beam technology}

The electron beam flue gas treatment process is one of the most promising technologies in modern environmental protection. This is a dry-scrubbing process of simultaneous $\mathrm{SO}_{2}$ and $\mathrm{NO}_{\mathrm{x}}$ reduction, where no waste except the by-product is generated. The by-product is fully usable as a fertilizer. Also VOCs present in flue gas may be reduced in this process [3]. This makes it possible to suggest that the electron beam process applied to VOCs decomposition might be an effective and economically viable method.

However, several studies have shown that this technology produces modifications in the concentrations of organic compounds, in particular PAH. The total PAH concentration and PAH-based overall toxicity of flue gas decreased. While results, gained at EPS Kaweczyn, show that the concentration of PAHs of small aromatic rings (p3, except acenaphthylene) is reduced, while the concentration of PAHs of large aromatic rings (X4) is increased. But results from other research showed that after irradiation, the concentrations of higher-ringed 
PAHs decrease and less-ringed PAHs increase [2, 15, 4, 61]. In another study the observed reduction efficiency for total PAHs was $85 \%$ [60].

TABLE 2

\section{GAS-PHASE PAH REMOVAL EFFICIENCY OVER VARIOUS METHODS $[81,19,46,60]$}

\begin{tabular}{|c|c|c|}
\hline Method & Substance & $\begin{array}{c}\text { Removal } \\
\text { efficiency, } \\
\text { \% }\end{array}$ \\
\hline $\mathrm{Pd} / \mathrm{Al}_{2} \mathrm{O}_{3}$ & Total PAHs & $67.3-93.5$ \\
\hline $\mathrm{Rh} / \mathrm{Al}_{2} \mathrm{O}_{3}$ & Total PAHs & 80 \\
\hline $\begin{array}{c}\text { Activated carbon } \\
\text { fibers }(\mathrm{ACFs})\end{array}$ & Total PAHs & 70 \\
\hline $\mathrm{Pd} / \mathrm{ACFs}$ & Total PAHs & $70.5-77.5$ \\
\hline $\begin{array}{c}\mathrm{HNO}-0,48 \% \\
\mathrm{Pd} / \mathrm{ACFs}\end{array}$ & Total PAHs & 96.5 \\
\hline $\begin{array}{c}\mathrm{NaOH}-0,52 \% \\
\mathrm{Pd} / \mathrm{ACFs}\end{array}$ & Total PAHs & 86 \\
\hline $0,53 \% \mathrm{Cu} / \mathrm{ACFs}$ & Total PAHs & 80 \\
\hline $1.63 \% \mathrm{Pt} / \mathrm{ACFs}$ & Total PAHs & 95 \\
\hline $\begin{array}{c}\text { Electron beam } \\
\text { technology }\end{array}$ & Total PAHs & 85 \\
\hline
\end{tabular}

\section{Wastewater treatment}

Biological treatment

There are two main types of biological treatment:

- activated sludge treatment, and

- percolating filters (also referred to as trickling or biological filters).

Both types of biological treatment require subsequent sedimentation to remove suspended matter from the oxidized effluent (Table 3) [41].

\section{Activated sludge treatment (AS)}

A conventional activated sludge treatment facility consists of a primary clarifier, an aerobic biological treatment stage and a secondary clarifier. There may be also added such treatment steps as sand filtration for removing suspended solids, activated carbon filtration for removing dissolved matter and biological/chemical treatment for removing $\mathrm{P}$ and $\mathrm{N}$.

In activated sludge treatment process is used oxygen and microorganisms to biologically oxidize organic pollutants. The produced sludge is partially recycled back to the aeration tank, which encourages rapid adsorption of pollutants in the incoming wastewater. The remaining waste sludge is removed for further treatment and ultimate disposal [69].

Depending on the mode of operation, the activated sludge treatment process may have up to four phases:

- clarification, by flocculation of suspended and colloidal matter;

- oxidation of carbonaceous matter;

- oxidation of nitrogenous matter;

- auto-digestion of the activated sludge [41].

In wastewater treatment plants, the majority of PAHs are typically bound to the sludge, thereby escaping aerobic treatment. Sorption to sludge particles is the main removal mechanism for PAHs (especially the heavier ones) during primary treatment, but during secondary treatment it is achieved by such processes as biodegradation or volatilization. Lower molecular weight
PAHs (naphthalene, acenaphthene, phenanthrene, anthracene, and fluoranthene) during secondary treatment show losses for more than $40 \%$ [35, 25, 64, 69]. Overall removal of 16 EPA PAHs ranged from 83-98.3\% [35, 63].

Some studies had demonstrated that concentrations of high molecular weight PAHs may increase during conventional wastewater treatment. Treatment plants had higher concentrations of HMW PAHs such as chrysene, pyrene, benzo(b)fluoranthene and benzo(k)fluoranthene than the incoming water. The largest increase was seen for pyrene [65].

As such pollutants as heavy metals and PAHs accumulate in the waste activated sludge it might not be possible to use it for farmland fertilization due to high levels of pollution.

\section{Biological filters $(\mathrm{BF})$}

Biological filters are generally used for removing organic pollutants from wastewater. The basic principle in a biofilter is biodegradation of pollutants by the microorganisms attached onto the filter media. There are three main biological processes that can occur in biofilter: attachment of microorganism; growth of microorganism; decay and detachment of microorganisms. The success of a biofilter depends on the growth and maintenance of microorganisms (biomass) on the surface of filter media [24].

\section{Membrane bioreactor (MBR)}

Membrane bioreactors are reduced-size installations with low sludge production, which allow for the direct reuse of the treated water, as a complete elimination of microorganisms in the effluent and a high removal ratio for most abiotic contaminants are achieved [56]. The studies showed that the removal efficiency of PAHs by MBR is thought to be in the order of $80 \%$ (effluent concentration $0-0.01 \mu \mathrm{g} / \mathrm{l})[36,38]$.

\section{Biofilm reactors}

Wastewater treatment systems using biofilms that grow attached to a support media are an alternative to the widely used suspended growth activated sludge process. Different fixed growth biofilm reactors are commercially used for the treatment of municipal as well as industrial wastewater. The use of submerged fixed bed biofilm reactors (SFBBR) is advantageous for the pre-treatment of industrial wastewater, especially for wastewater with high organic loading or high content of compounds with low biodegradability [75].

The MBfR is based on membranes that deliver a gaseous substrate to a biofilm, while also serving as its substratum. The technology offers unique advantages to conventional biofilm treatment technologies and provides specialized treatment for a wide variety of reduced, oxidized, and organic compounds. After several decades of bench and pilot-scale research, the MBfR finally is reaching maturity. The development of the first commercial scale process, ARoNite ${ }^{\mathrm{TM}}$, is a significant milestone in MBfR development. If the process is 
successful, the same reactor configuration could be used to treat a wide range of water and wastewater contaminants. More basic and applied research on the life expectancy, cost, and reliability of the MBfR will allow the technology to provide a cost-effective, sustainable solution for water and wastewater treatment [45].

Biological aerated filtration (BAF)

Conventionally, BAF is submerged media wastewater treatment reactors that combine biological treatment and biomass separation by depth filtration. It adopts a granular media as the support for microbial biofilms that also provides the depth filtration action. The system does not require special maintenance operations and assures low management costs $[48,33]$.

Granular activated carbon-fluidized bed reactor (GAC-FBR)

GAC-FBR is an ex situ technology for the treatment of groundwater, wastewater and process water contaminated with hydrocarbons and other organic pollutants. It combines the advantages of biological and physical treatment in a single unit operation, by employing GAC as the solid support for biofilm growth in a fluidized-bed reactor. Aqueous waste streams containing organic contaminants such as benzene, toluene, ethylbenzene and xylenes (BTEX) and PAHs are treatable with this technology. Overall PAH removals of $>99 \%$ were observed at high organic loading rates and a hydraulic retention time of about $6 \mathrm{~min}$. Removal of 2- to 4-ring PAHs was found to be due primarily to biological oxidation and not to adsorption [39, 68]. However, it is worth noting that high concentrations of total organic carbon over $100 \mathrm{mg} / \mathrm{l}$ may need a denitrifying mode of operation. This would require large process volumes and the handling of nitric acid and/or nitrates [32].

\section{Hypersol Macronet (MN200)}

Searching for suitable sorbents for polycyclic aromatic hydrocarbons (PAHs) removal from aqueous solutions that solve many of the existing problems when using granulated-activated carbon, a new type of nonfunctionalized macroporous hyper cross-linked resin, Hypersol Macronet (MN200) had been evaluated. Due to the lack of precise information on the PAH sorption process by hyper-cross-linked resins, it is unlikely that a rigorous kinetic model can be developed. The Fick's law (HDM) approach and the shell progressive model were used to fit some experimental data. As a first approximation both models can be used in the study of the PAH extraction processes by the hyper-cross-linked MN200 resin [22].

Sorption of six PAHs (acenaphthene, anthracene, fluoranthene, fluorine, naphthalene and pyrene) on activated carbon and the Macronet polymeric sorbent MN200 was investigated to determine the effectiveness of each sorbent for removal of pollutants from aqueous solution and their possible use as sorbent materials for groundwater. Activated carbon showed better sorption efficiency with maximum loadings of PAHs between 90 and $230 \mathrm{~g} / \mathrm{kg}$, while MN200 resin showed values of 25$160 \mathrm{~g} / \mathrm{kg}[21]$.

\section{TABLE 3}

PAH REMOVAL EFFICIENCY USING DIFFERENT BIOLOGICAL WASTEWATER TREATMENT METHODS $[35,36,38,25,63,64,69$, $57,68]$

\begin{tabular}{|c|c|c|}
\hline Method & Substance & $\begin{array}{c}\text { Removal } \\
\text { efficiency, \% }\end{array}$ \\
\hline $\begin{array}{c}\text { Activated } \\
\text { sludge } \\
\text { treatment } \\
\text { (secondary } \\
\text { treatment) }\end{array}$ & $\begin{array}{c}\text { naphthalene, } \\
\text { acenaphthene, } \\
\text { phenanthrene, } \\
\text { anthracene, } \\
\text { fluoranthene }\end{array}$ & $>40$ \\
\cline { 2 - 3 } Total PAHs & $83-98.3$ \\
\hline $\begin{array}{c}\text { Membrane } \\
\text { bioreactor }\end{array}$ & Total PAHs & $\sim 80$ \\
\hline $\begin{array}{c}\text { Biofilm } \\
\text { reactors }\end{array}$ & Total PAHs & $>99.7$ \\
\hline $\begin{array}{c}\text { Granular } \\
\text { activated } \\
\text { carbon- } \\
\text { fluidized bed } \\
\text { reactor }\end{array}$ & Total PAHs & $>99$ \\
\hline \multicolumn{2}{|c|}{} \\
\hline
\end{tabular}

\section{Chemical oxidation}

Chemical oxidation modifies the structure of pollutants in wastewater to similar, but less harmful, compounds through the addition of an oxidizing agent (Table 4). During chemical oxidation, one or more electrons transfer from the oxidant to the targeted pollutant, causing its destruction [86].

\section{Ozone Oxidation}

Ozone $\left(\mathrm{O}_{3}\right)$ is a strong oxidant with an oxidation potential. $\mathrm{O}_{3}$ reacts with organic contaminants through either direct reactions or through the formation of free radicals, including the hydroxyl radical $(\bullet \mathrm{OH})$. The $\bullet \mathrm{OH}$ exposure $(! \cdot \mathrm{OH} \mathrm{dt})$ can be determined through the use of para-chlorobenzoic acid (pCBA), an $\mathrm{O}_{3}$-resistant probe compound which reacts selectively with $\cdot \mathrm{OH}$. Ozonation processes are particularly attractive because ozone can destroy hazardous organic contaminants [62, 58]. In studies indicated treatment efficiencies for ozonation of $50-90 \%$ for PAH (effluent concentrations $0-0.01 \mu \mathrm{g} / \mathrm{L}$ ) $[36,38]$.

Ozone oxidation can be operated with UV irradiation. In this system up to three pathways of organic compound removal can develop: direct photolysis, direct ozonation and radical oxidation. The hydroxyl radicals result from the decomposition of ozone due to photolysis and a reaction with hydroxyl anion which produces hydroxyl radicals in subsequent reactions. The $\cdot \mathrm{OH}$ radicals react without selectivity on numerous organic chemicals in water. The further reaction course is more complicated as primary products compete for ozone, hydroxyl radicals and UV radiation with the target compound. Organic molecules excited by UV radiation can react with oxygen and ozone. Additionally, intermediates can decompose giving radical species which can take part in the reaction. Oxygen, usually delivered to the reaction mixture with 
ozone, is also suspected of participation in the oxidation process [73].

The ozonation combined with UV radiation is an effective and quick method for selected PAHs removal from the aqueous environment. The highest rate of degradation is achieved in acidic solutions and the slowest in alkaline solutions. The process carried out in the presence of hydroxyl radical scavenger suggests that benzo(a)pyrene and chrysene decomposition follows the radical reaction to some extent, but for fluorene it is not so obvious. The comparison of the three methods of PAHs degradation using $\mathrm{O}_{3}$, UV radiation and $\mathrm{O}_{3} / \mathrm{UV}$ system permit to state that the combined process is the most effective [73].

A novel method for the degradation of PAH by ozonation, using a mixture of polar and nonpolar solvents, followed by bacterial biodegradation of the oxygenated intermediates was recently disclosed. The method involves dissolving ozone in a bipolar solvent which is contacted with the PAH compounds to solubilise them and to react them with the ozone. The bipolar solvent is then mixed with water to form separate non-polar and polar phases, and the polar phase is incubated with bacteria to biodegrade the oxygenated intermediates [67].

Ozone can also be combined with hydrogen peroxide. UV wavelengths of 200-280 nm lead to disassociation of $\mathrm{H}_{2} \mathrm{O}_{2}$, with mercury lamps emitting at $254 \mathrm{~nm}$ being the most commonly used. $\mathrm{UV} / \mathrm{H}_{2} \mathrm{O}_{2}$ systems generate hydroxyl radicals which are highly powerful oxidizing species. Hydroxyl radicals can oxidize organic compounds producing organic radicals, which are highly reactive and can be further oxidized [70].

$\mathrm{UV} / \mathrm{H}_{2} \mathrm{O}_{2}$ proved to be an effective treatment method for the degradation of phenanthrene and pyrene solubilized in perfluorinated surfactant solutions. The application of $\mathrm{H}_{2} \mathrm{O}_{2}$ dramatically enhanced the photolysis of the PAHs in both water and anionic surfactant solutions compared to direct photolysis. Surfactant solutions retarded the photolysis of phenanthrene and enhanced the photolysis rate of pyrene [82].

The oxidation of fluorene, phenanthrene, and acenaphthene in water was studied by applying UV radiation combined with $\mathrm{H}_{2} \mathrm{O}_{2}$. Disappearance rates of PAHs were found to be substantially increased with respect to those from UV radiation alone when the right conditions of $\mathrm{H}_{2} \mathrm{O}_{2}$ concentration and $\mathrm{pH}$ were established. The contribution of direct photolysis decreased with increasing $\mathrm{H}_{2} \mathrm{O}_{2}$ concentration and was the main way of degradation at acid $\mathrm{pH}(76 \%$ at $\mathrm{pH} 2$ with $10^{-3} \mathrm{M} \mathrm{H}_{2} \mathrm{O}_{2}$ concentration, for fluorene oxidation). Both $\mathrm{UV}$ radiation and $\mathrm{UV} / \mathrm{H}_{2} \mathrm{O}_{2}$ oxidation of PAHs yield numerous intermediate compounds, but most of these compounds disappear as the oxidation time is increased [28].

The study in which had been investigated treatment of fluorene, phenanthrene, and acenaphthene in water with ozone combined with hydrogen peroxide showed that the presence of $\mathrm{H}_{2} \mathrm{O}_{2}$ did not improve the oxidation rate of fluorene, phenanthrene, and acenaphthene in water compared to ozonation alone. Concentrations of $\mathrm{H}_{2} \mathrm{O}_{2}$ lower than 0.01 $\mathrm{M}$ did not yield significant variations of PAH degradation rate, and at higher $\mathrm{H}_{2} \mathrm{O}_{2}$ concentrations the process was inhibited, suggesting that direct reactions of ozone with PAHs are so important that the contribution of hydroxyl radical oxidation has no effect on the rate of PAH oxidation. It was concluded that, although ozone combined with UV radiation allows for the highest oxidation rates, the differences with respect to ozonation alone are so small that in a practical case it is likely that the cost associated with the use of UV radiation makes ozonation alone the more convenient technology to remove PAHs from water [29].

The process of photocatalytic oxidation is based on the production of electron-hole pairs by illumination with light of suitable energy, of a semiconductor powder dispersed in an aqueous medium, which subsequently react with adsorbed species of suitable redox potential. In the presence of air, adsorbed molecular oxygen accepts photogenerated electrons, while water molecules can react with photogenerated holes to produce hydroxyl radicals $[49,72]$.

Fluorene was used as a model PAH compound to compare the efficiency of six different oxidation methods: single ozonation $\left(\mathrm{O}_{3}\right)$, single adsorption $\left(\mathrm{TiO}_{2}\right)$, ozone photolysis $\left(\mathrm{UVA} / \mathrm{O}_{3}\right), \mathrm{TiO}_{2}$ photocatalysis $\left(\mathrm{TiO}_{2} / \mathrm{UV}_{\mathrm{A}}\right)$, $\mathrm{TiO}_{2}$ catalytic ozonation $\left(\mathrm{TiO}_{2} / \mathrm{O}_{3}\right)$, and $\mathrm{TiO}_{2}$ photocatalytic ozonation $\left(\mathrm{TiO}_{2} / \mathrm{UVA} / \mathrm{O}_{3}\right)$. At a fixed $\mathrm{pH}$, the reactivity order for fluorene oxidation was $\mathrm{TiO}_{2} / \mathrm{UVA} / \mathrm{O}_{3}>\mathrm{UVA} / \mathrm{O}_{3}>\mathrm{O}_{3} \approx \mathrm{TiO}_{2} / \mathrm{O}_{3} \approx \mathrm{TiO}_{2} / \mathrm{UVA}>$ $\mathrm{TiO}_{2}$. The ozone photocatalytic process $\left(\mathrm{TiO}_{2} / \mathrm{UVA} / \mathrm{O}_{3}\right)$ showed the highest performance, while UV photolysis alone did not yield any fluorene removal. For ozone photocatalysis, total mineralization was achieved in less than 10 and $15 \mathrm{~min}$ at $\mathrm{pH} 5$ and 2, respectively, and for ozone photolysis at $\mathrm{pH}$ 5. Approximately 50\% mineralization was reached in photocatalytic oxidation and when ozone alone or combined with $\mathrm{TiO}_{2}$ was applied [31].

\section{Fenton oxidation}

Fenton oxidation is widely accepted as efficient and environmental friendly process, the generation of sludge due to the flocculation of organic Fe(III) complexes and $\mathrm{Fe}(\mathrm{III})$ hydroxides at elevated $\mathrm{pH}$ values presents its disadvantage. However, introduction of ultrasound or ultraviolet irradiation in the systems lead to the enhancement of the Fenton oxidation, making it more competitive in terms of efficiency with other chemical oxidation methods (Table 4). Such processes are known as sono-Fenton and photo-Fenton process [37].

Fenton Oxidation is an advisable process for total degradation of PAHs such as, phenanthrene and acenaphthene in water within a few minutes, provided the reagent concentrations are optimized. At low concentrations, ferrous ion and hydrogen peroxide act as initiators of hydroxyl radicals, whereas at high concentrations they slow the oxidation rate. The best concentrations seem to be $10^{-3} \mathrm{M}$ for hydrogen peroxide and $7 \times 10^{-5} \mathrm{M}$ for ferrous ion, and the $\mathrm{pH}$ of the water should be near 7 [30]. 
TABLE 4

PAH REMOVAL EFFICIENCY USING CHEMICAL OXIDATION METHODS [36, 38, 73, 16, 28, 50, 31]

\begin{tabular}{|c|c|c|c|}
\hline \multirow{3}{*}{ Method } & Substance & $\begin{array}{c}\text { Removal } \\
\text { efficiency } \\
(\boldsymbol{\%})\end{array}$ & $\begin{array}{c}\text { Reaction } \\
\text { rate } \\
\text { constant k, } \\
\mathbf{M}^{-1} \mathbf{s}^{-1}\end{array}$ \\
\hline \multirow{3}{*}{ Ozonation } & Total PAHs & $50-90$ & \\
\cline { 2 - 4 } & benzo[a]pyrene & & $6.2 \times 10^{4}$ \\
\cline { 2 - 4 } & fluorene & & 29 \\
\hline \multirow{4}{*}{$\mathrm{O}_{3} / \mathrm{UV}$} & benzo[a]pyrene & & $6.8 \times 10^{4}$ \\
\cline { 2 - 4 } & chrysene & & $6.9 \times 10^{3}$ \\
\cline { 2 - 4 } & fluorene & & 62 \\
\cline { 2 - 4 } & Total PAHs & $\sim 100$ & $9.9 \times 10^{9}$ \\
\hline \multirow{3}{*}{$\mathrm{UV}^{3} \mathrm{H}_{2} \mathrm{O}_{2}$} & fluorene & & $8.8 \times 10^{9}$ \\
\cline { 2 - 4 } & acenaphthene & & $13.4 \times 10^{9}$ \\
\cline { 2 - 4 } & phenanthrene & & \\
\hline $\mathrm{Fe}^{3+} / \mathrm{H}_{2} \mathrm{O}_{2} / \mathrm{UV}^{2}$ & Total PAHs & $>90$ & \\
\hline $\mathrm{TiO}_{2} / \mathrm{UVA}_{3} / \mathrm{O}_{3}$ & fluorene & $\sim 50$ & \\
\hline
\end{tabular}

\section{Biosorbents}

Recently there has been increasing interest in $\mathrm{PAH}$ removal by biosorbents. There are already done some researches in this field using different kinds of materials such as:

- plant residues (ryegrass, alfalfa, tomato, potato, pumpkin, carrot and zucchini roots, cucumber, orange peel, bamboo leaf, pine needles and bark, tender and mature tea leaves, wood chip, cork waste) [85, 51, 17, 23, 84];

- algae (Botryococcus braunii, brown seaweed) $[54,55]$;

- white-rot fungi [18];

- modified biosorbents (aspen wood fiber, hydrolyzed wood fibers, brewed tender and mature tea leaves, acid hydrolysis of pine bark, fibric peat and surfactant modified fibric peat) $[23,84,47,78]$;

- nature organic matter (lignin, cellulose, collagen, cuticle of apple, grape, tomato, potato and mangrove) [54, 83].

Comparing all these sorbents and activated carbon by partition coefficient $(\mathrm{Kd})$, which is an effective parameter to evaluate the sorption efficiency, shows that their removal efficiency for PAHs is more or less lower.

However, should not be forgotten the fact that raw plant materials are easily modified to enhance the sorption capability. Thus some of these natural adsorbents are potential alternatives of activated carbon in an innovative approach for the removal of this class of toxic compounds, and significantly reduce the regeneration costs of the process (Table 5) $[85,51,17,23,84,54,55$, $18,47,79,83]$.
TABLE 5

PAH REMOVAL EFFICIENCY USING DIFFERENT BIOSORBENTS [17, 85, 84, 54, 55, 47, 79, 83]

\begin{tabular}{|c|c|c|}
\hline \multicolumn{2}{|r|}{ Sorbent } & $\log K_{d}$ \\
\hline \multirow{16}{*}{$\begin{array}{l}\text { Plant } \\
\text { residues }\end{array}$} & Ryegrass root & 3.44 \\
\hline & Wood chip & 3.40 \\
\hline & Orange peel & 3.47 \\
\hline & Bamboo leaf & 3.57 \\
\hline & Pine needles & 3.72 \\
\hline & Alfalfa root & 3.37 \\
\hline & Tomato root & 3.40 \\
\hline & Potato root & 3.62 \\
\hline & Pumpkin root & 3.62 \\
\hline & Carrot root & 3.70 \\
\hline & Zucchini root & 3.66 \\
\hline & Cucumber & 3.52 \\
\hline & Ryegrass root & 3.32 \\
\hline & Pine bark & 3.53 \\
\hline & Tender tea leaves & $3.52-3.54$ \\
\hline & Mature tea leaves & $3.77-4.05$ \\
\hline \multirow{2}{*}{ Algae } & Botryococcus braunii & 4.13 \\
\hline & Brown seaweed & 3.83 \\
\hline Fungi & White-rot fungi & 3.83 \\
\hline \multirow{8}{*}{$\begin{array}{l}\text { Modified } \\
\text { biosorbents }\end{array}$} & Aspen wood fiber & $3.60-3.67$ \\
\hline & $\begin{array}{c}\text { Low-temperature } \\
\text { hydrolyzed wood fibers }\end{array}$ & 4.03-4.15 \\
\hline & $\begin{array}{c}\text { High-temperature } \\
\text { hydrolyzed wood fibers }\end{array}$ & $4.63-4.75$ \\
\hline & Brewed tender tea leaves & $3.76-3.80$ \\
\hline & Brewed mature tea leaves & $3.95-4.20$ \\
\hline & $\begin{array}{c}\text { Acid hydrolysis of pine } \\
\text { bark }\end{array}$ & 4.23 \\
\hline & Fibric peat & 4.11 \\
\hline & $\begin{array}{c}\text { Surfactant modified fibric } \\
\text { peat }\end{array}$ & 4.42 \\
\hline \multirow{8}{*}{$\begin{array}{c}\text { Nature } \\
\text { organic } \\
\text { matter }\end{array}$} & Lignin & 4.03 \\
\hline & Cellulose & 2.98 \\
\hline & Collagen & 4.47 \\
\hline & Cuticle of mangrove & 4.21 \\
\hline & Cuticle of apple & 4.73 \\
\hline & Cuticle of grape & 4.54 \\
\hline & Cuticle of tomato & 4.61 \\
\hline & Cuticle of potato & 4.21 \\
\hline
\end{tabular}

\section{CONCLUSIONS}

One of the most notable anthropogenic sources of PAH emissions are power plants, waste incineration plants and industrial enterprises, therefore it is important to minimize the emissions from them. Exists a wide variety of methods for PAH abatement, but a part of them are not developed specifically to treat them. They were originally created for abatement of other types of pollutants and are used for general treatment of wastewater or flue gases, however there is studied also the influence on $\mathrm{PAH}$ emissions.

Flue gas treatment methods, that are generally used for the collection of particulate matter or dust (cyclone separators, bag filters, wet scrubbers, electrostatic precipitators), showed rather low removal efficiency. For total PAHs it ranged only from 11.7 to $42.5 \%$.

Much better results showed metals supported catalysts. The removal efficiency of them depending on metalcatalyst combination ranges from 67.3 to $96.5 \%$.

In the wastewater treatment field very promising results shows recently developed technologies that are based on 
biofilms, but they are not yet widely used industrially because they still faces challenges, including biofilm management, the design of scalable reactor configurations, and the identification of cost-effective membranes.

The combination of ozone with UV radiation allows for the highest PAH degradation levels. However the high costs constitute a restriction on the use of this method.

All in all there is still being sought for the best PAH treatment methods that would be both efficient and costeffective. None single emission control technology that is available nowadays, is not efficient enough, while the combination of technologies is recognized as the best approach.

\section{REFERENCES}

[1] A. Aranda, M. V. Navarro, T. Garcia,, R. Murillo, A. M. Mastral, "Temperature swing adsorption of polycyclic aromatic hydrocarbons on activated carbons," Ind. Eng. Chem. Res., vol. 46 no. 24, pp. 8193-8198, October 2007.

[2] A. G. Chmielewskia, A. Ostapczuka, Z. Zimeka, J. Lickib, K. Kubica, "Reduction of VOCs in flue gas from coal combustion by electron beam treatment," Rad. Phys. Chem., vol. 63, pp. 653-655, March 2002.

[3] A. G. Chmielewski, A. Pawelec, B. Tymiski, Z. Zimek, J. Licki, "Industrial applications of electron beam flue gas treatment," in Emerging applications of radiation processing, 2004, pp. 153-161.

[4] A. G. Chmielewskia, Y. X. Suna, J. Lickib, S. Bulkaa, K. Kubicac, Z. Zimek, " $\mathrm{NO}_{\mathrm{x}}$ and PAHs removal from industrial flue gas by using electron beam technology with alcohol addition," Rad. Phys. Chem., vol. 67, pp. 555-560, June 2003.

[5] A. Laitinen, K. Vaaraslahti, J. Keskinen, "Preformed Spray Scrubber-Comparison of Precipitation Mechanisms for Charged Fine Particles," J. Aerosol Sci., vol. 31, pp. 158-159, 2000.

[6] A. M. Mastral, M. S. Callen, "Review on Polycyclic Aromatic Hydrocarbon emissions in energy generation," Environ. Sci. Technol., vol. 15, pp. 3051-3057, July 1999.

[7] A. M. Mastral, M. S. Callen, R. Murillo, T. Garcia, "Polycyclic Aromatic Hydrocarbons (PAH) and organic matter (OM) relationship in the particulate matter emitted from atmospheric fluidised bed coal combustion (AFBC)," Environ. Sci. Technol., vol. 33, no. 18, pp. 3177-3184, August 1999.

[8] A. M. Mastral, M. S. Callen, R. Murillo, T. Garcia, "Toxic organic emissions from coal combustion,” Fuel Proc. Technol., vol. 67, pp 1-10, June 2000.

[9] A. M. Mastral, T. Garcia, R. Murillo, M. S. Callen, J. M. Lypez, M V. Navarro, "Moisture effects on the phenanthrene adsorption capacity by carbonaceous materials," Energy Fuel, vol. 16, pp. 205-210, November 2002

[10] A. M. Mastral, T. García, R. Murillo, M. S. Callén, J. M. López, M. V. Navarro, "Development of efficient adsorbent materials for PAH cleaning from AFBC hot gas," Energy Fuels, vol. 18, no. 1, pp. 202-208, 2004.

[11] A. M. Mastral, T. Garcia, M. S. Callén, M. V. Navarro, J. Galbán, "Removal of Naphthalene, Phenanthrene, and Pyrene by Sorbents from Hot Gas," Environ. Sci. Technol., vol. 35, no. 11, pp. 2395 2400, 2001

[12] A. M. Mastral, T. Garcia, M. S. Callén, R. Murillo, M. V. Navarro, J. M. Lopez, "Sorbent characteristics influence on the adsorption of PAC: I. PAH adsorption with the same number of rings," F. Proc. Tech., vol. 77-78, pp. 373-379, June 2002.

[13] A. M. Mastral, T. Garcia, R. Murillo, S. Callen, J. M. Lopez, M. V. Navarro,"PAH mixture removal from hot gas by porous carbons. From model compounds to real conditions," Indust. Eng. Chem. Res., vol 42, no. 21, pp. 5280-5286, 2003.

[14] A. M. Mastral, T. Garcia, M. S. Callén, J. M. Lopez, M. V. Navarro, R. Murillo, J. Galbán, "Three-ring PAH removal from waste hot gas by sorbents: Influence of the sorbent characteristics," Environ. Sci. Technol., vol. 36, no. 8, pp. 18211826, March 2002.

[15] A. Ostapczuka, J. Lickib, A. G. Chmielewski, "Polycyclic aromatic hydrocarbons in coal combustion flue gas under electron beam irradiation," Rad. Phys. Chem., vol. 77, pp. 490-496, April 2008.

[16] A. Wenzel, A. Gahr, R. Niessner, "TOC-removal and degradation of pollutants in leachate using a thin-film photoreactor," Water Research, vol. 33, no. 4, pp. 937-946, March 1999.

[17] B. Chena, M. Yuana, H. Liua, "Removal of polycyclic aromatic hydrocarbons from aqueous solution using plant residue materials as a biosorbent," J. Haz. Mat., vol. 188, pp. 436-442, February 2011.

[18] B. Chen, Y. Wang, D. Hu, "Biosorption and biodegradation of polycyclic aromatic hydrocarbons in aqueous solutions by a consortium of white-rot fungi," J. Hazard. Mater., vol. 179, pp. 845-851, July 2010.

[19] C. Feng-Yim, C. Jyh-Cherng, W. Ming-Yen, "The activity of $\mathrm{Rh} / \mathrm{Al}_{2} \mathrm{O}_{3}$ and $\mathrm{Rh}-\mathrm{Na} / \mathrm{Al}_{2} \mathrm{O}_{3}$ catalysts for PAHs removal in the waste incineration processes: Effects of particulates, heavy metals, and acid gases," Fuel, vol. 88, pp. 1563-1571, September 2009.

[20] C. H. Wang, S. S. Lin, C. L. Chen, H. S. Weng, "Performance of the supported copper oxide catalysts for the catalytic incineration of aromatic hydrocarbons," Chemosphere, vol. 64, pp. 503-509, June 2006

[21] C. Valderrama, X. Gamisans, J. L. Cortina, A. Farran, F. X. de las Heras, "Evaluation of polyaromatic hydrocarbon removal from aqueous solutions using activated carbon and hyper-crosslinked polymer (Macronet MN200),' J. Chem Tech. Biotech., vol 84, no. 2, pp. 236-245, February 2009.

[22] C. Valderrama, X. Gamisans, F. X. de las Heras, J. L. Cortina, A. Farrarn, "Kinetics of polycyclic aromatic hydrocarbons removal using hyper-cross-linked polymeric sorbents Macronet Hypersol MN200," React. Func. Polym., vol. 67, no. 12, pp. 1515-1529, December 2007.

[23] D. Lin, B. Pan, L. Zhu, B. Xing, "Characterization and phenanthrene sorption of tea leaf powders," J. Agric. Food Chem., vol. 55, pp. 5718-5724, 2007.

[24] D. S. Chaudhary, S. Vigneswaran, H. H. Ngo, W. G. Shim, H. Moon, "Biofilter in water and wastewater treatment," Korean J. Chem. Eng., vol. 20, no. 6, pp. 1054-1065, November 2003.

[25] E. Manoli, C. Samara, "Occurrence and mass balance of polycyclic aromatic hydrocarbons in the Thessaloniki sewage treatment plant," J. of Environ. Qual., vol. 28, pp. 176-187, 1999.

[26] E. Ntainjua, N. A. F. Carley, S. H. Taylor, "The role of support on the performance of platinum-based catalysts for the total oxidation of polycyclic aromatic hydrocarbons," Catal. Today, vol. 137, pp. 362-366, September 2008.

[27] E. Ntainjua, N. T. Garcia, S. H. Taylor, "Naphthalene oxidation over vanadiummodified Pt catalysts supported on $\gamma-\mathrm{Al}_{2} \mathrm{O}_{3}$," Catal. Lett., vol. 110, pp. 125-128, August 2006.

[28] F. J. Beltran, G. Ovejero, J. F. Rivas, "Oxidation of polynuclear aromatic hydrocarbons in water.3. UV radiation combined with hydrogen peroxide," Indust. Eng. Chem. Res., vol. 35, pp. 883 $890,1996$.

[29] F. J. Beltran, G. Ovejero, J. Rivas, "Oxidation of polynuclear aromatic hydrocarbons in water.4. Ozone combined with hydrogen peroxide," Indust. Eng. Chem. Res., vol. 35, pp. 891-898, 1996.

[30] F. J. Beltran, J. F. Rivas, O. Gimeno, M. Carbajo, "Photocatalytic enhanced oxidation of fluorene in water with ozone. Comparison with other chemical oxidation methods," Indust. Eng. Chem. Res., vol. 44, pp. 3419-3425, 2005.

[31] F. J. Beltran, M. Gonzalez, J. F. Rivas, P. Alvarez, "Fenton reagent advanced oxidation of polynuclear aromatic hydrocarbons in water," Water, Air and Soil Pollution, vol. 105, pp. 685-700, 1998.

[32] H. D. Ryu, D. Kim, H. E. Lim, S. I. Lee, "Nitrogen removal from low carbon-to-nitrogen wastewater in four-stage biological aerated filter system," Proc. Bioch., vol. 43, pp. 729-735, July 2008.

[33] H. H.Yanga, R. C. Junga, Y. F. Wangb, L. T. Hsiehc, "Polycyclic aromatic hydrocarbon emissions from joss paper furnaces," Atm. Envir., vol. 39, pp. 3305-3312, 2005.

[34] H. Melcer, P. Steel, W. K. Bedford, "Removal of polycyclic aromatic hydrocarbons and heterocyclic nitrogen compounds in a municipal treatment plant," Water Environ. Res., vol. 67, pp. 926934, 1995.

[35] H. Wenzel, H. F. Larsen, J. Clauson-Kaas, L. Hoibye, B. N. Jacobsen, B.N., (2008) "Weighing environmental advantages and disadvantages of advanced wastewater treatment of micropollutants using environmental life cycle assessment," Water Sci. Technol., vol. 57, pp. 27-32, 2008

[36] I. Grčic, M. Maljkovic, S. Papic, N. Koprivanac, "Low frequency US and UV-A assisted Fenton oxidation of simulated dyehouse wastewater,” J. Haz. Mat., vol. 197, pp. 272-284, December 2011. 
[37] J. F. Clausson-Kaas, F. Dahl, F., Dalgaard, L. Hoibye, J. Kjolholt, H. Wenzel, H. F. Larsen, "Advanced treatment of urban wastewater," COWI, May 2006.

[38] J. H. Lehr, Wiley's remediation technologies handbook: major contaminant chemicals and chemical groups. John Wiley \& Sons, Inc., 2004.

[39] J. J. Cudahy, R. W. Helsel, "Removal of products of incomplete combustion with carbon," Waste Manage, vol. 20, pp. 339-45, October 2000

[40] J. Lester, D. Edge, "Sewage and Sewage Sludge Treatment," in Pollution - Causes, Effects and Control, 4th edition, Ed. R.M. Harrison: Royal Society of Chemistry, 2001.

[41] J. L. Shie, C. Y. Chang, J. H. Chen, W. T. Tsai, Y. H. Chen, C. S. Chiou, C. F. Chang, "Catalytic oxidation of naphthalene using a $\mathrm{Pt} / \mathrm{Al}_{2} \mathrm{O}_{3}$ catalyst," Appl. Catal. B: Environ. vol. 58, pp. 289-297, June 2005.

[42] J. P. Forgac, „Continuous clean bag filter apparathus and method,” U. S. Patent 4,411,674, October 25, 1983.

[43] J. Zucker, "Electrostatic precipitator and method," U. S. Patent 3,984,215, October 5, 1976.

[44] K. J. Martin, R. Nerenberg, "The membrane biofilm reactor (MBfR) for water and wastewater treatment: Principles, applications, and recent developments," Biores. Tech., vol. 122 pp. 83-94, October 2012.

[45] L. Chiou-Liang, C. Yu-Hsiang, L. Zhen-Shu, C.Jian-Yuan, "Meta catalysts supported on activated carbon fibers for removal of polycyclic aromatic hydrocarbons from incineration flue gas," $\mathrm{J}$. Haz. Mat., vol. 197, pp. 254- 263, December 2011

[46] L. Huang, T. B. Boving, B. Xing, "Sorption of PAHs by aspen wood fibers as affected by chemical alterations," Environ. Sci. Technol., vol. 40, pp. 3279-3284, 2006.

[47] L. Mendoza-Espinosa, T. Stephenson, "A review of biological aerated filters for wastewater treatment," Environ. Eng. Sci., vol. 16, no. 3, pp. 201-216, 1999.

[48] L. Sánchez, J. Peral, X. Domènech, "Aniline degradation by combined photocatalysis and ozonation," Appl. Catal., vol 19, no. 1, pp. 59-65, October 1998.

[49] M. A. Engwall, J. J. Pignatello, D. Grasso, "Degradation and detoxification of the wood preservatives creosote and pentachlorophenol in water by the photo-Fenton reaction," Water Research, vol. 33, no. 5, pp. 1151-1158, April 1999.

[50] M. A. Olivella, P. J. Oliveras, A. Oliveras, "The use of cork waste as a biosorbent for persistent organic pollutants-Study of adsorption/desorption of polycyclic aromatic hydrocarbons," J. Environ. Sci. Health, vol.46, no. 8, pp. 824-832, May 2011.

[51] M. F. Dehne, „Cyclone separator,” U. S. Patent 300,859, April 9, 1974.

[52] M. H. Yuana, C. Y. Changa, J. L. Shieb, C. C. Changa, J. H. Chena, W. T. Tsaic, "Destruction of naphthalene via ozonecatalytic oxidation process over $\mathrm{Pt} / \mathrm{Al}_{2} \mathrm{O}_{3}$ catalyst," J. Haz. Mat. vol. 175, pp. 809-815, March 2010.

[53] M. J. Salloum, B. Chefetz, P. G. Hatcher, "Phenanthrene sorption by aliphatic-rich natural organic matter," Environ. Sci. Technol., vol. 36, pp. 1953-1958, 2002.

[54] M. K. Chung, M. T. K. Tsui, K. C. Cheung, N. F. Y. Tam, M. H Wong, "Removal of aqueous phenanthrene by brown seaweed Sargassum hemiphyllum: sorption-kinetic and equilibrium studies," Sep. Purif. Technol., vol. 54, pp. 355-362, May 2007.

[55] M. Molina-Mucoz, J. M. Poyatos, M. M. Sanchez-Peinado, E. Hontoria, J. Gonzalez-Lypez, B. Rodelas, "Microbial community structure and dynamics in a pilot-scale submerged membrane bioreactor aerobically treating domestic wastewater under real operation conditions," Sci. Total Environ., vol. 407, no. 13, pp. 3994-4003, June 2009.

[56] M. M. Zein, P. X. Pinto, S. Garcia-Blanco, M. T. Suidan, A. D. Venosa, "Treatment of groundwater contaminated with PAHs, gasoline hydrocarbons, and methyl tert-butyl ether in a laboratory biomass-retaining bioreactor," Biodegradation (2006), vol. 17, pp. 57-69, February 2006.

[57] M. Pena, M. Coca, G. Gonzalez, R. Rioja, M. T. Garcia, "Chemical oxidation of wastewater from molasses fermentation with ozone," Chemos., vol. 51, pp. 893-900, June 2003.

[58] M. R. Morales, B. P. Barbero, L. E. Cadus, "Combustion of volatile organic compounds on manganese iron or nickel mixed oxide catalysts," Appl. Catal. B: Environ., vol. 74, pp. 1-10, June 2007.

[59] M. S. Callén, M. T. de la Cruz, S. Marinov, A. M. Mastral, R. Murillo, M. Stefanova, "Hot gas cleaning in power stations by using electron beam technology. Influence on PAH emissions,' Fuel Processing Technology, vol. 88, pp. 273-280, March 2007.

[60] M. S. Callén, M. T. de la Cruz, S. Marinov, R. Murillo, M. Stefanova, A. M. Mastral, "Flue gas cleaning in power stations by using electron beam technology. Influence on PAH emissions," F. Proc. Tech., vol. 88, pp. 251-258, March 2007.

[61] M. S. Elovitz, U. von Gunten, "Hydroxyl radical/ozone ratios during ozonation processes. I. The $\mathrm{R}_{\mathrm{ct}}$ concept. Ozone Association," Sci. and Eng., vol. 21. no 3, pp. 239-260, 1999.

[62] M. Wlodarczyk-Makula, "The loads of PAHs in wastewater and sewage sludge of municipal treatment plant," Polycyclic Aromatic Compounds, vol. 25, pp. 183-194, 2005.

[63] N. Christensen, D. J. Batstone, Z. He, I. Angelidaki, J. E. Schmidt, "Removal of polycyclic aromatic hydrocarbons (PAHs) from sewage sludge by anaerobic degradation," Water Sci. Technol., vol. 50, pp. 237-244, 2004.

[64] P. A. Bergqvist, L. Augulyte, V. Jurjoniene, "PAH and PCB removal efficiencies in Umea (Sweden) and Siauliai (Lithuania) municipal wastewater treatment plants," Water Air and Soil Pollution, vol. 175, pp. 291-303, March 2006

[65] P. Gelin, M. Primet, "Complete oxidation of methane at low temperature over noble metal based catalysts: a review,"Appl. Catal. B: Environ., vol. 39, pp. 1-37, March 2002

[66] P. K. A. Hong., D. A. Wavrek, J. C. Chao, Y. Zeng, "Degradation of polycyclic aromatic hydrocarbons to render them available for biodegradation." USPTO Patent Application 20080242875, March 24, 2008.

[67] R. F. Hickey, A. Sunday, D. Wagner, V. Groshko, R. V. Rajan, A. Leuschner, T. D. Hayes, Treatment of PAHs in waters using the GAC-FBR process. Third international in situ and onsite Bioreclamation Symposium, April 24-27, 1995, San Diego, CA (U.S.): Battelle Press, 1996.

[68] R. S. Ramalho, Introduction to Wastewater Treatment Processes. London: Academic Press, 1977.

[69] R. Venkatandri, W. R. Peters, "Chemical oxidation technologies: ultraviolet light/hydrogen peroxide, Fenton's reagent, and titaniumdioxide-as sisted photocatalysis," Haz. Waste Haz. Mater, vol. 10 , no. 2, pp. 107-149, 1993.

[70] S. C. Kim, "The catalytic oxidation of aromatic hydrocarbons over supported metal oxide," J. Hazard. Mater., vol. 91, pp. 285-299, April 2002.

[71] S. Gomes de Moraes, R.S. Freire, N. Durán,"Degradation and toxicity reduction of textile effluent by combined photocatalytic and ozonation processes," Chemos., vol. 40, no. 4, pp. 369-373, February 2000.

[72] S. Ledakowicz, J. S. Miller, D. Olejnik, "Oxidation of PAHs in water solution by ozone combined with ultraviolet radiation," Intern. J. Photoen., vol. 3, pp. 95-101, 2001.

[73] S. R. Cowley, B.S. McCoy, "Wet scrubber apparatus," U. S. Patent 5,178,654, January 12, 1993.

[74] S. Schlegel, H. Koeser, (2007) "Wastewater treatment with submerged fixed bed biofilm reactor systems - design rules, operating experiences and ongoing developments," Water Sci. Technol., vol. 55, pp. 83-89, 2007.

[75] T. Hayes, D. Arthur, "Overview of emerging produced water treatment technologies," presented at 11th Annual International Petroleum Environmental Conference, Albuquerque, NM, October 12-15, 2004

[76] W. J. Lee, M. C. Liow, P. J. Tsai, L. T. Hsieh, "Emission of polycyclic aromatic hydrocarbons from medical waste incinerators," Atm. Envir., vol. 36, pp. 781-790, 2002.

[77] W. J. Lee, W. H. Chao, M. Shih, C. H. Tsai, T. J. H. Chen, P. J. Tsai, "Emissions of Polycyclic Aromatic Hydrocarbons from Batch Hot Mix Asphalt Plants,” Environ. Sci. Technol., vol. 38 , no. 20, pp 5274-5280, September 2004.

[78] X. Tang, Y. Zhou, Y. Xu, Q. Zhao, X. Zhou, J. Lu, "Sorption of polycyclic aromatic hydrocarbons from aqueous solution by hexadecyltrimethylammonium bromide modified fibric peat," J. Chem. Technol. Biotechnol., vol. 85, pp. 1084-1091, 2010.

[79] X. W. Zhang, S. C. Shen, L. E. Yu, S. Kawi, K. Hidajat, K. Y. S. $\mathrm{Ng}$, "Oxidative decomposition of naphthalene by supported metal catalysts," Appl. Catal. A: Gen., vol. 250, pp. 341-352, June 2003.

[80] Y. F. Zhang, C. He, Q. Xu, J. S. Chen, "Oxidation characteristics of polycyclic aromatic hydrocarbons in flue gas over $\mathrm{Pd} / \gamma-\mathrm{Al}_{2} \mathrm{O}_{3}$ catalyst," J. Fuel Chem. Technol., vol. 39, no. 7, pp. 543-549, July 2011.

[81] Y. J. An, e. R. Carraway, "PAH degradation by $\mathrm{UV} / \mathrm{H}_{2} \mathrm{O}_{2}$ in perfluorinated surfactant solutions," Water Research., vol. 36, pp. 309-314, January 2002. 
Semjonova I., Teirumnieks E. A REVIEW OF METHODS FOR REDUCTION OF POLYCYCLIC AROMATIC HYDROCARBONS FROM WASTE WATER AND FLUE GASES

[82] Y. Li, B. Chen, "Phenanthrene sorption by fruit cuticles and potato periderm with different compositional characteristics," J. Agric. Food Chem., vol. 57, pp. 637-644, 2009.

[83] Y. Li, B. Chen, L. Zhu, "Enhanced sorption of polycyclic aromatic hydrocarbons from aqueous solution by modified pine bark," Bioresour. Technol. vol. 101, pp. 7307-7313, 2010.

[84] Y. Zhu, S. Zhang, Y. Zhu, P. Christie, X. X. Shan, "Improved approaches for modeling the sorption of phenanthrene by a range of plant species,” Environ. Sci. Technol., vol. 41, pp. 7818-7823, 2007.

[85] United States Anvironmental Protection Agency, "Pollution Prevention Guidance Manual for the PFPR Industry." [Online]. Available: http://water.epa.gov/scitech/wastetech/ guide/pesticides /upload/1998_05_26_guide_p2_pdf_ch5.pdf. [Accessed: Feb. 4, 2013] 